\title{
Interpretation of the Soul in the Qur'an (A Study of the Perspective of Sheikh Abdul al-Qadir al-Jilani in Tafsir al-Jilani)
}

\author{
$1^{\text {st }}$ Muhammad Iman Maedi ${ }^{1}, 2^{\text {nd }}$ Kusmana $^{2}, 3^{\text {rd }}$ Imam Subchi $^{3}$ \\ \{muhammad.iman18@mhs.uinjkt.ac.id ${ }^{1}$, kusmana@uinjtk.ac.id ${ }^{2}$, imam.subchi@uinjkt.ac.id ${ }^{3}$ \}
}

UIN Syarif Hidayatullah Jakarta ${ }^{1,2,3}$

\begin{abstract}
The interpretation of the soul in the Qur'an has different meanings, according to the context of the verses. The definition of the word soul is defined by the commentators almost the same as one another, but in Tafsir al-Jilani, the word soul is defined in a different sense with a sufistic nuance and has its own message and impression. Then, how the word soul is explained with the sufistic characteristics attached to the interpreter's side, this paper wants to explain the interpretation of the soul in the Qur'an from the side of s,ufistic interpretation so that the message and impression of the meaning soul in Qur'an can be understood.
\end{abstract}

Keywords: Soul, Qur'an, Sheikh Abdul Qadir al-Jilani.

\section{Introduction}

In the development of Islamic thought, the discourse on the soul is a very interesting thing to discuss. On the one hand, belief in the soul is strength, understanding and is related to one's religious beliefs. On the other hand, the soul can also be explained systematically, in detail and logically, so that research on the soul is something that needs to be studied in depth.

In this case the understanding of the soul in the Qur'an has various meanings according to the context in each verse, but basically the understanding related to the soul is a substantial thing that belongs to God, but on the other hand the understanding of the soul in the Qur'an can be understood by discussion by the commentators and provide understanding by inserting messages and values from the meaning of the soul itself.

\section{Methodology}

This research uses an intertext analysis approach with a qualitative method of verses concerning the soul in Tafsir al-Jilani. On the one hand, for the method, the method of collection uses the main source and other supporting data to express the purpose of certain thoughts on a topic. From the data used, it is the main data through thematic studies in grouping verses about the soul in the book of Tafsir al-Jilani.

From this method, the final result obtained is a Sufistic interpretation of the soul in each of the verses of the Qur'an and an explanation of various values that are different from other commentators in interpreting the verses about the spirit in the Qur'an. Thus, in the end, the 
definition of soul in the Qur'an can be understood from the perspective of the Sufistic interpretation described by Sheikh Abdul Qadir al-Jilani in Tafsir al-Jilani.

\section{Result and Discussion}

\subsection{Definition of Soul}

The definition of the soul is interpreted differently by philosophers and scholars, according to Ibnu Sina the meaning of the soul is an initial perfection of the natural human body that is noble and has a life with a power, on the other hand al-Farabi defines the soul as something that comes from the realm of command that has different characteristics of the body (Ibn Qayyim Az-Jauziyyah, 2015: 289)

Meanwhile, Ibn Qayyim al-Jauziyyah said that the soul is a noble body of conscience, moving life that can penetrate all members of the body and spread within humans. In contrast to Ibn Qayyim, according to al-Ghazali, the soul has two meanings, the first is physical and spiritual. The physical spirit is a soft substance that is dotted in the heart room and then spreads to all the veins in the entire body and makes humans able to move and feel various feelings and can make humans think, while the spiritual spirit is an unseen thing that cannot be known and define. (Ramadan Lubis, 2021)

Allah gives the potential elements for humans so that humans are different from other creatures, humans are created from soil and the divine spirit with a process that is not mentioned in great detail[1]. Humans are creatures consisting of physical and spiritual dimensions accompanied by naturally inherent elements such as souls and forms responsive to the environment that cause human behavior[2]. The human soul has a rational and imaginary super immaterial that cannot be divided or explained, but does not mean that it can be interpreted in terms of its existence, and the soul is part of the nature of divinity and the nature of Muhammadiyah[3].

The meaning of the word soul in the dictionary is essence, the truth of the object and the word spirit is used in several verses in the Qur'an, the difference in the meaning of the word spirit can be concluded in the emphasis on meaning, humans, essence and truth of objects[4].

\subsection{The Various Meaning of Soul in Qur'an}

The meaning of the word soul in the Qur'an has several meanings according to the context of the existing word, either before or after it. The following is the meaning of the word soul in the Qur'an:

- The word $r u \bar{h}$ which is interpreted as something (element) that is in the body created by God as the cause of life (life).

It was found ini Qs. an-Nisa(4) :171, Qs. al-Hijr(15) :29, Qs. al-Isra (17): 85, Qs. alAnbiyā(21) : 91, Qs. as-Sajadah(32) : 9, Qs. Shād(38) : 72, Qs. at-Tahrīm(66) : 12

- $\quad$ The word ruh which is meaning as Jibril, it was found in Qs. al-Baqarah(2)

: 87, Qs. al-Baqarah(2) : 253, Qs. al-Maidah(10) : 110, Qs. an-Nahl(16) : 102, Qs.

Maryam(19) : 17, Qs asy-Syu'ārā(26) : 193, Qs. al-Ma'ārij(70) : 4, Qs an-Naba(78) : 38, Qs. al-Qadr( 97) : 4 
- The word Rūh which is meaning Qur'an, it was found ini Qs an- Nahl(16) : 2, Qs. alGhāfir(40) : 15, Qs. asy-Shūra(42) : 52

- $\quad$ The word ruh which is meaning help from Allah Swt, it was in Qs. al- Mujādalah(58) : 22, grace from Allah Swt in Qs. Yusuf(12) : 87, peace in in Qs. al-Wāqi'ah(56) : 89.



Fig. 1. Various meaning of Soul.

\subsection{Interpretation of Soul in Tafsir al-Jilani}

In Qs. al-Isra verse 8, the Sheikh explains that the soul in the verse is the Essence that unites with the body and becomes the mover of the body. In line with the explanation in Qs. Al-Hijr verse 29, when Allah SWT has perfected the human form of a land then Allah SWT sprinkled His Spirit (the light of His form) into that form, with the aim that there is an element of the Most Living Allah and as a representation of Allah SWT in realizing the names and attributes of Allah. His nature on earth. In line with his interpretation in Qs. Shad[5].

As for in Qs. an-Nisa verse 171 the word soul is defined as the form of His Tajalli, when Allah SWT conveys a sentence to Siti Maryam and then blows the soul with a specificity to the nature of lahuthiah which overlies the nature of nashutiyah. Moreover in Qs. al-Baqarah verse 87 the word spirit is defined as the angel Gabriel, the spirit of al-Quds or the holy spirit from every bad trait, deficiency and ugliness in Qs. al-Ghafir verse 15 the spirit is defined in the meaning of revelation or the Qur'an. 
This is in line with Qs. al-Isra Syeih Abdul Qadir al-Jilani interprets the spirit in that verse as a substance that is united with the body and becomes the promoter of the body to move according to its own will. In line with his interpretation in Qs. al-Hijr verse 29 when God created man and when his form was perfect then God sprinkled the spark of the spirit, namely the light of His form so that later when the human was alive, there would be an element of His Most Life as well so that humans could become a medium or representative of Allah SWT to realize the name and His character in the world.

On another interpretation in Qs. as-Sajadah, he added that when Allah swt breathed His Spirit it was a majesty and privilege which stated that humans are His extraordinary creations which have His element, namely Hadrah Rububiyyah.

In another interpretation of the spirit in the Qur'an, namely the interpretation of the spirit in the context of Prophet Isa who was born to a mother without a father, namely Mary. Sheikh Abdul Qadir al-Jilani explained that when Allah swt breathed His spirit into Siti Maryam's stomach it was a form of His tajalli which showed His specificity so that the nature of lahuthiah overcame the nature of nasuthiah.

The discussion of the spirit in Tafsir al-Jilani can also be clarified by the understanding of the soul which he described in the book Sirrur al-Asrar wa Mazharul al-Anwar, where the soul is defined according to its phases. In the realm of the sea (the first realm the spirit is in), namely the spirit of al-Quds or the soul of al-Quds al-Insani al-Haqiqi which is in the deepest part of the heart that is attached to the sentence of monotheism. In the second phase, when the spirit is in the mulk realm or the natural world, the spirit is wrapped with the body or spirit alphysical. This is in line with the discussion of the spirit in its interpretation that humans are representatives of their nature and name [6].

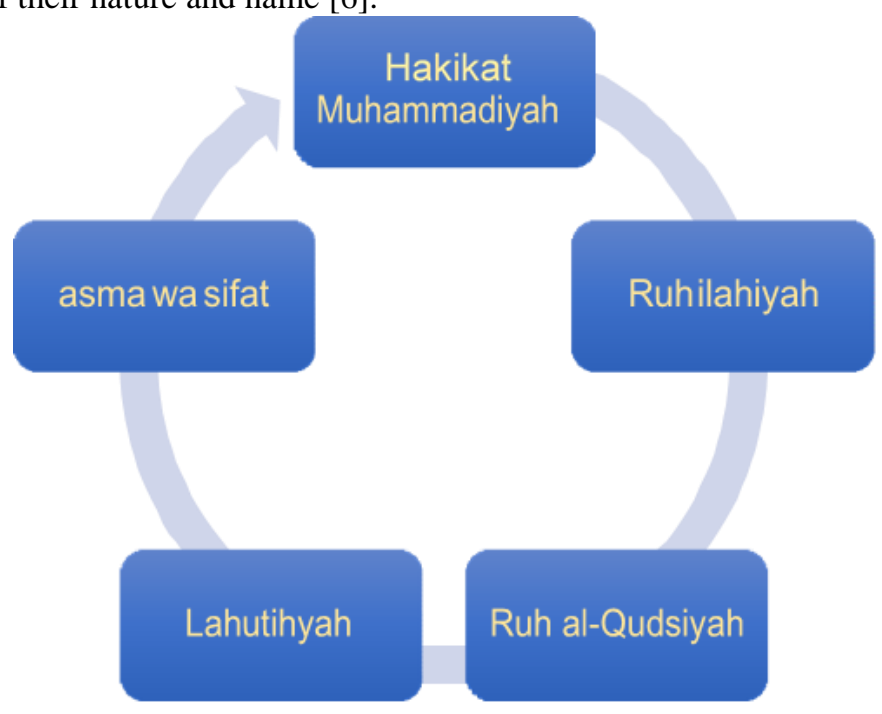

Fig. 2. Interpretation of Soul.

\section{Discussion}

The interpretation of the soul in the Qur'an has various meanings, but most scholars of interpretation interpret the spirit as something that is the domain of Allah, which is difficult to 
understand. On the other hand, Sheikh Abdul Qadir al-Jilani explained with a different interpretation from a Sufistic point of view, that the spirit referred to in the Qur'an is actually the essence of Muhammadiyah, all spirits that exist on earth originate from it. But on the other hand, the spirit is defined as a divine spirit whose purpose is that humans can become representatives of the attributes and names of Allah in this world.

Acknowledgments. There is no reply that the author can give other than prayers and thanks, may Allah SWT accept good deeds, give His blessing to us, give us recompense for all his efforts and may we all be in His protection. Good grief. The author is fully aware that this journal is far from perfect. Therefore, both suggestions and criticisms from readers are very much expected for further improvements. Finally, the author would like to express his deepest gratitude to Allah SWT and hopefully this journal will be useful for the authors in particular and all parties in general. 


\section{References}

[1] Hassan el-Rmady, Soils and Human Creation in the holy Qur'an: from Point of View of Soil Science," Environment, Biodiversity and Soil Security 2019 h. 1-9

[2] J Warsah, Dimension of Soul in the Qur'an an Islamic Physchological Perspective In Jurnal Pemikiran Islam, v. 25 no, 2 h. 295-314.

[3] A. Dirbaz, The Philosophical-Mystical Expression of the Super Immateriality Station of the soul on the Basis of Qur'an Verses and Narrations, v. 25, no. 98, 2020.

[4] Zeinab Sadat Rouhani, Conceptology of Soul (Nafs) in the Quran dalam Journal of Qur'an and Medicine, vol, 4, no.5 2020.

[5] Abdul Qadir al-Jilani, Tafsir al-jilani (Beirut : Dar Al-Kotob Al-

Ilmiyah, 2014), cet 2, jilid 1 h. 441-442

[6] Syekh Abdul Qadir al-Jilani, Sirrur al-Asrar wa Mazharul al-Anwar, Tangeran Cilongok Press, 2012. 